\title{
COMMUNITY DEVELOPMENT AND THE COMMUNITY NURSE
}

\author{
VAL WOODWARD \\ ORGANISER OF NURSING SERVICES, \\ DEPARTMENT OF HEALTH, WELFARE AND PENSIONS
}

\section{OPSOMMING}

Gemeenskappe moet die verantwoordelikheid vir hulle eie gesondheidsorg begin aanvaar. Dit kan slegs bewerkstellig word indien gesondheidspersoneel die gemeenskapsontwikkelingsbenadering begin toepas.

Gemeenskapsontwikkeling is wanneer die gemeenskap van hulle behoeftes bewus word en hulle eie bronne inspan om in hierdie behoeftes te voorsien.

Vir gemeenskapsont wikkeling moet die verpleegkundige die gemeenskap stimuleer om hulle ontevredenheid te analiseer, hul behoeftes te bepaal en daarop te reageer, terwyl sy slegs in 'n rigtinggewende hoedanigheid optree. Dit is alleen moontlik indien sy aanvaar dat elke individu uniek is en potensiaal het, dat alle mense goeie en swak eienskappe het waarvan die goeies versterk moet word en dat, wanneer klein doelwitte bereik word, dit as stimulus dien om groter take aan te pak.

Die gemeenskapsverpleegkundige moet gemeenskapsontwikkeling nie as 'n addisionele taak beskou nie. Dit is een van die alternatiewe oplossings vir pasiëntprobleme wat in die verpleegproses in verband met gemeenskapsorg oorweeg moet word.

\section{ORIENTATION}

I

$\mathrm{n}$ the health professions lip service has long been paid to the concept of people accepting responsibility for the maintenance of their own health. Yet, in reality, in spite of extensive health education campaigns to bring this home to the communities served, there is still a marked tendency to think for - to plan for - and to do for - people those things which, if provided with adequate stimulation, they could well think about - plan. - and execute - for themselves.

But in this era of ever-increasing costs coupled with a shortage of manpower in the health professions, we cannot afford the doubtful luxury of continuing along these lines. Hence, as nurses, we must start to use the community development approach in total health management. We must stop believing that this is confined to the work of the sociologist, the economist, educationist, professional community development worker - or, in fact, to any of the helping professions other than our own.

The community development idea was originally linked to the improvement of socio-economic conditions in Third World countries once the industrialised countries of the West had recovered from the impact of the Second World War. It was only during the fifties that community development came to be regarded as the process whereby the efforts of the people themselves were united with those of governmental agencies to improve economic, social and cultural conditions - and, by implication, the health of the community.

Seeking a definition of community development, one finds that the literature abounds in these, each reflecting the orientation of its author. For the purpose of this presentation two definitions seem to indicate most effectively the concept as it is currently finding expression:

According to Biddle and Biddle $(1965: 78)^{2)}$, the community development process is . . a progression of events that is planned by the participants to serve goals they progressively choose. The events point to changes in a group and in individuals that can be termed growth in social sensitivity and conciousness... a social process by which human beings can become more competent to live with and gain some control over local aspects of a frustrating and changing world.

In the Community Development Review (1956:1) the concept is defined as... a process of social action in which the people of a community organize themselves for planning and action; define their common and individual needs and problems; . . . execute these plans with a maximum of reliance upon community resources; and supplement these resources when necessary with services and materials from governmental and non-governmental agencies outside the community. (Quoted by Biddle and Biddle: 1965: 78$)^{2)}$

It would be appropriate to pause here and consider whether there is a difference between community development and community involvement. The author believes there is. Where an organised group, such as Lions International or the Vrouefederasie, becomes aware of a particular need in a community and, taking the initiative, recruits its own resources to meet this need in cooperation with concerned, but not necessarily affected, members of the community - this is community involvement. It makes an indispensable contribution to the wellbeing of many communities.

Conversely, where people in a community become aware of their own common needs and mobilise their own resources to meet these needs, they are participating in a process of community development. The reader may feel that this distinction amounts to hair-splitting - and perhaps it is. Nevertheless, the author is of the opinion that the attainment of the personal growth and independence implicit in the above definition necessitates this differentiation. 


\section{THE COMMUNITY DE- VELOPMENT PROCESS}

Ideally, the community development process should be initiated when a group within a community recognises a common need and acts spontaneously and co-operatively to solve the problem; and undoubtedly this has always happened in some communites without outside intervention. situations the community is so depressed physically, socially and emotionally that its members lack the basic motivation to take any communal action. Similarly, where the degree of social disorganisation is high, members of the community are only vaguely aware of a common life - let alone of a need for communal action. It is in these areas that the nurse can act as a catalyst in bringing about community development projects.

Many of the early efforts at community development met with only li-
However, it is also true that in many

mited success while community development workers - the so-called agents of change - exhausted themselves in directing community projects. They believed that the community members were not capable of recognising their own needs, nor of meeting them without expert planning, coercion and guidance.

It is in the nature of man to be deeply committed only to those decisions which he has taken for himself. Only when community development workers recognised this and adopted what is now termed as the non-directive technique was community development successfully launched.

Then how can the community nurse get community development off the ground in a depressed, apathetic community, using a non-directive approach? Batten and Batten (1967: 47) ${ }^{\mathrm{l}}$ suggested a process as shown in Diagram 1.

This diagram shows that to help the

\section{Diagram 1: Stages in the Process Leading to Action by a Group}

State of members
of the Group

The Nurse's Role

(by asking questions)

Stage 1 Vaguely dissatisfied but passive

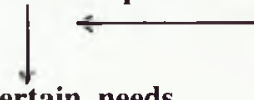

Stimulates people to think why they are dissatisfied and with what.

Stage 2 Now aware of certain needs

Stimulates people to think about what specific change would result in the need being met.

Stage 3 Now aware of wanting changes of some specific kind.

Stimulates people to consider what they might do to bring such changes about by taking action themselves

Stage 4 Decided for, or against, trying to meet some want for themselves.

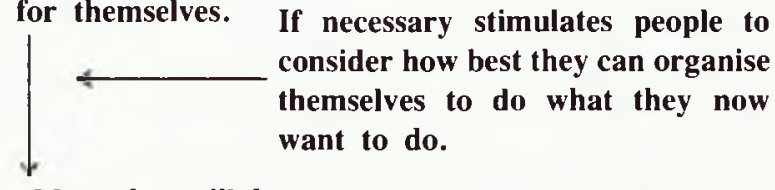

Stage 5 Plan what to do and how they will do it.

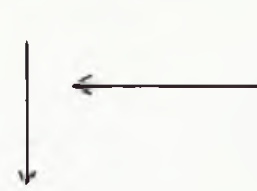

Stage 6 Act according to their planning

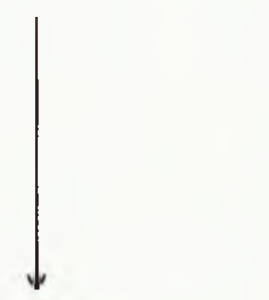

Stage 7 Satisfied with the result of what they have achieved? again need to help them work through each of the preceding tages in deciding how to tack each problem)

Stimulates people to think through any unforeseen difficulties or probems they may encounter in the course of what they do. (She may

(Adapted from Batten \& Batten, 1967:47) coinmunity to move from stage one to stage two, the community development worker - in this case the nurse stimulates people to analyse their dissatisfactions in order to become aware of their underlying needs. To be able to fulfil this role successfully, the nurse must herself be aware of the needs of the community - both the needs which are termed felt needs and those which she recognises as a health professional. This will entail a thorough study of the community, in other words, the preparation of a comprehensive community profile.

Two salient points must be emphasised in this regard. First, the compilation of such a profile should not be seen as another task for the already busy community nurse - should she not have such information at her finger tips in any case? Secondly, it is absolutely vital for the nurse to record this information so that she has a valid baseline against which to measure the effect of her efforts to effect meaningful community development and indeed to measure her work in providing a health service.

Recognising the needs of the community, the nurse should also consider possible solutions so that she will be in a position to facilitate the transfer from stage two to stage three and thence to the subsequent stages. Furthermore she must be able to analyse the actions suggested and planned by the group and to encourage them to set realistic objectives. This will enable her to pinpoint the responsibilities involved in the implementation of plans.

An example may serve to clarify this point: if a group of women living in an overcrowded, built-up area have decided that they will find premises, funds and equipment to set up a creche or play-area for their children, it is the task of the community development worker to make them aware that once started, the crèche will be their responsibility someone will have to supervise the children, maintain the equipment, and keep the project running.

Another approach which has been applied successfully in stimulating community development is along the road of health education. An intriguing account by Skeet ${ }^{31}$ illustrates this point.

At a meeting in Columbia a group of parents was introduced to the procedure for measuring the brachial circumference on their own children. The instrument was a specially designed cardboard strip with differently coloured bands at strategic intervals indicating whether the child was well-nourished, in danger of malnutrition, or 
frankly malnourished. To the consternation of many of the parents, they found that their children fell into the second and third categories.

Under the guidance of the health worker, they analysed the problem and discovered for themselves that the major causes of their children's underdevelopment were poor nutrition, parasitic infestation, impure drinking water, and infections. The next step was to discover long-term solutions. The community members themselves planned and implemented projects to improve nutrition, to purify water supplies, to combat parasitic infestation and arranged for professional assistance in mounting immunisation campaigns.

To carry any project to its logical conclusion, evaluation of what has been achieved is essential. Reference has already been made to the necessity for preparing a comprehensive community profile against which to measure progress. Long-term achievements could, for example, be measured against improvements in the infant mortality rate, the incidence of infectious diseases, the number of clinic attendances and so on.

The key objective of community development is the development of the people themselves - and this is more difficult to evaluate in measureable terms. However, it is probably valid to say that evidence of development of people could be found in their spontaneous desire to tackle another problem by communal action.

In addition, the community nurse needs to compare the amount of time she devoted to fulfilling her role in the community development process with the amount of time she would have spent dealing with the problem by other means. She will also evaluate what the project has meant to her in terms of job satisfaction (a subjective evaluation which should not be underestimated).

\section{THE DEMANDS OF COMMUNITY DEVELOPMENT}

To function effectively as a facilitator of community development, the nurse must subscribe to certain assumptions regarding the people in the community.

First, that every individual is valuable and unique, and has the potential to grow to greater social awareness and responsibility. This means that each individual needs encouragement to enable him to develop latent abilities initiative, originality and leadership tend to emerge and thrive when people work together for the common good.

Secondly, all humans and groups have both good and bad impulses. The community development worker has an important role in encouraging people to strengthen the good in themselves, and in supporting them in their choice of the ethically better alternative in the variety of courses of action open to them.

The third assumption is that the achievement of small objectives provides the stimulus to tackle increasingly difficult problems which leads to continuing growth.

Workers who have launched successful community development projects seem to have certain vital characteristics in common. Chief amongst these, is an unfailing optimism about people and a belief in the human potential for growth. This is coupled with an ability to convey this optimism and belief to the people among whom one works. The greatest accolade which could be applied to a worker in this field is: She always makes me feel as if I am worth something!

Can the busy community nurse meet such demands? Working as she often does in very difficult circumstances in communities where social pathologies abound, where motivation for self-development is low, and where health problems are legion, it is not surprising that she tends to become disillusioned.

But she is really the only member of the health team who is a familiar and usually respected confidante of a large portion of the community. She should use this position to its full advantage. Perhaps she needs assistance in taking an objective look at the community; in identifying their strengths and weaknesses; in considering whether any of her busy-ness could be better dealt with by the community itself.

\section{TRAINING NURSES TO APPLY THE COMMUNITY DE - VELOPMENT PRINCIPLE}

Since April 1980 the Department of Health. Welfare and Pensions has offered a number of courses in community development for community nurses in the departmental services. The objectives of the courses were to introduce the concept of community development to the nurses, to give them an opportunity of considering their communities objectively and of determining which of the health problems might best be tackled by a non-directive community development approach. An attempt was made to bring home to course participants that community development should be a way of thinking for the nurse.

In applying the nursing process action is planned to solve various problems which have been identified during the assessment phase. Such planning takes into account all the alternative solutions to the problem and the nurse selects the most appropriate. It is in this manner that the community nurse should be thinking community development as one of the possible solutions to various health problems in the community.

The course participants were thus encouraged to view community development as an integral part of the work they are already doing - not as another task added to the daily workload.

Since attending the courses, many of the participants have been successful in initiating community development projects in their regions. Projects have varied from the erection of pit latrines in a rural area, to the integration of the residents in a home for the aged into the surrounding community in an urban area. A project which attracted particular notice involved (among other aspects) the establishment of school and home gardens, the refurbishing of a neglected clinic building and the beautification of the environment. This project which took place in a rural area has had a valuable ripple-effect to surrounding communities. Leaders and other interested people from these communities have visited the area and have embarked enthusiastically on their own projects.

In summary then, it can be said that the application of community development in health work is an essential element of the work of the modern community nurse. The process can be initiated effectively by the nurse because of her close contact with the community and her trusted position within the community. Ideally her approach should be a non-directive one in which she plays the role of stimulator and encourager.

To do this successfully, she must be lieve wholeheartedly that, given the right encouragement, the members of the community have the ability to act co-operatively to meet their own needs and wants.

\section{CONCLUSION}

Many community nurses will be feeling that there is nothing new here - and they are right in many respects. Community development is not new to community nurses - but the conscious application of a scientifically valid process may be.

To those who are doing it already more power to you! To those who are not - why not give it a try?

\section{BIBLIOGRAPHY}

1. Batten, T.R.; Batten, M. The non-directive approach in group and community work. Oxford University Press. London. 1967

2. Biddle, W.W.; Biddle, L.J. The community development process; Holt, Rinehart and Winston. New York. 1965.

3. Roux, J.P. Community development. Opening address at first course in community development for nurses. De partment of Health, Welfare and Pensions. April 1980

4. Skeet, Muriel. Building on what they have. Nursing Mirror. Vol 152 No 21. May 20 1981. p. 26-28. 